\title{
Basal cell carcinoma of the nose
}

Nick F Logarakis, Michael J Weinberg BSc MSc MD, Oleh M Antonyshyn MD FRCSC, Christopher R Forrest MD MSc FRCSC, Dalal Assaad MD FRCPC, Ida Ackerman MD FRCPC

Division of Plastic Surgery, Departments of Dermatology, Pathology and Radiation Oncology, Skin Cancer Clinic, Toronto Sunnybrook Regional Cancer Centre, Toronto, Ontario

NF Logarakis, MJ Weinberg, OM Antonyshyn, CR Forrest, D Assaad, I Ackerman. Basal cell carcinoma of the nose. Can J Plast Surg 1995;3(2):74-78. The goal of this study was to determine the demographic features, clinical presentation and treatment of basal cell carcinomas of the nose. To this end, a retrospective chart review of 229 patients, who presented to the Toronto Sunnybrook Regional Cancer Centre between January 1990 and January 1993, was conducted. There were 229 malignancies in 229 consecutive patients. Sixty-six percent of the patients were female and the overall mean age was 70 years. The ala was the most common site followed by the tip, lateral nose, dorsum, alar groove, root and columella. There were no cases of metastases. One hundred and two patients were treated with surgery and 101 patients received radiotherapy. The remainder were treated with electrodessication and curettage. Various methods of reconstruction were used and are discussed. This study demonstrates the various presentations of basal cell carcinoma of the nose and the usefulness and roles of a multidisciplinary team in its assessment and treatment.

Key Words: Basal cell cancer, Radiation, Surgery

\section{Carcinome basocellulaire du nez}

RÉSUMÉ : L'objectif de cette étude était de déterminer les caractéristiques démographiques, la présentation clinique et le traitement du carcinome basocellulaire du nez. À cette fin, un tableau synthétique rétrospectif sur 229 patients qui se sont présentés au Sunnybrook Regional Cancer Centre de Toronto entre janvier 1990 et janvier 1993 a été constitué. Deux cent vingt-neuf néoplasies ont été diagnostiquées chez 229 patients consécutifs. Soixante-six pour cent des patients étaient de sexe féminin et la moyenne d'âge globale était de 70 ans. L'aile du nez était le site le plus fréquent, suivie du bout du nez, de l'aile du nez, du dos, du sillon de l'aile, de la racine et de la columelle. Aucun cas de métastase n'a été noté. Cent deux patients ont été traités chirurgicalement et 101 patients ont reçu une radiothérapie. Les autres ont été traités par électrodessication et curetage. Diverses méthodes de reconstruction ont été utilisées et sont présentées ici. Cette étude décrit plusieurs présentations du carcinome basocellulaire du nez, ainsi que l'utilité et le rôle de l'équipe pluridisciplinaire dans son évaluation et dans son traitement. 
Basal cell carcinomas are the most common malignancies in Caucasians, in whom they occur almost exclusively (1). They usually present in patients between the ages of 50 and 70 years old (2-5). Eighty-five percent of tumours are located in the head and neck area (6), of which 25 to $30 \%$ occur on the nose $(7,8)$. On the nose the ala is the most frequently involved anatomical site $(2,5)$. Although slow growing and unlikely to metastasize, these tumours may have an indolent course and are prone to recurrence if inadequately treated. If neglected, tumour related destruction of anatomic features can create difficult reconstructive challenges.

There are several standard treatment modalities including electrodessication and curettage, radiotherapy and surgery. Indications for each are distinct and thus for optimal management a team approach is necessary.

The purpose of this paper is to review the experience at a regional cancer centre, featuring a multidisciplinary approach to skin cancer treatment. Demographics, clinical and pathological features and the use of various treatment modalities in the treatment of basal cell carcinomas of the nose are specifically assessed.

\section{MATERIALS AND METHODS}

This is a retrospective study of 229 consecutive patients presenting with basal cell carcinoma (BCC) of the nose, from January 1990 to January 1993. All patients were seen at the Toronto Sunnybrook Regional Cancer Centre (TSRCC).

All patients were assessed in the TSRCC by a multidisciplinary team, consisting of plastic surgery, dermatology, radiation oncology and dermatopathology. All patients had a biopsy-proven basal cell carcinoma at the time of referral. Patient assessment and decisions regarding optimal management were conducted jointly by all members of the team. Treatment options included electrodessication, curettage, surgical excision (with or without frozen section), radiotherapy and combination therapy.

A standardized data sheet was designed and used to record all the pertinent variables. These variables included demographic data, tumour data and treatment modality employed. Collected data were entered and analyzed in a database program (File maker Pro, Claris Corp) on a Macintosh computer.

\section{RESULTS}

Demographics: There were 229 tumours in 229 consecutive patients. Sixty-six percent of these patients were female and $34 \%$ were male. The average age was 66.9 years with a range of 27 to 97 years.

Tumour presentation: The vast majority of the tumours (70.3\%) were new presentations (Figure 1). However, a significant proportion of these tumours were recurrent $(17.5 \%)$, residual following previous excision elsewhere $(10 \%)$, or radiorecurrent $(2.2 \%)$.

Histopathology: Nodular basal cell carcinomas made up 59\% of the tumours. The other $41 \%$ were made up of sclerosing (34.9\%), basosquamous cell (2.6\%), superficial (3.5\%) and pigmented basal cell carcinomas (0.4\%) (Figure 2).

Anatomic distribution: The anatomic distribution of these tumours is depicted in Figure 3 . The most frequent location for these malignancies was the nasal ala (31.5\%). The next most common area was the nasal tip (26.6\%) followed by the lateral nose $(20.7 \%)$, dorsum $(10.8 \%)$ and alar groove $(9.8 \%)$. Skin tumours occurred infrequently at the nasal root $(0.3 \%)$ and columella $(0.3 \%)$. 


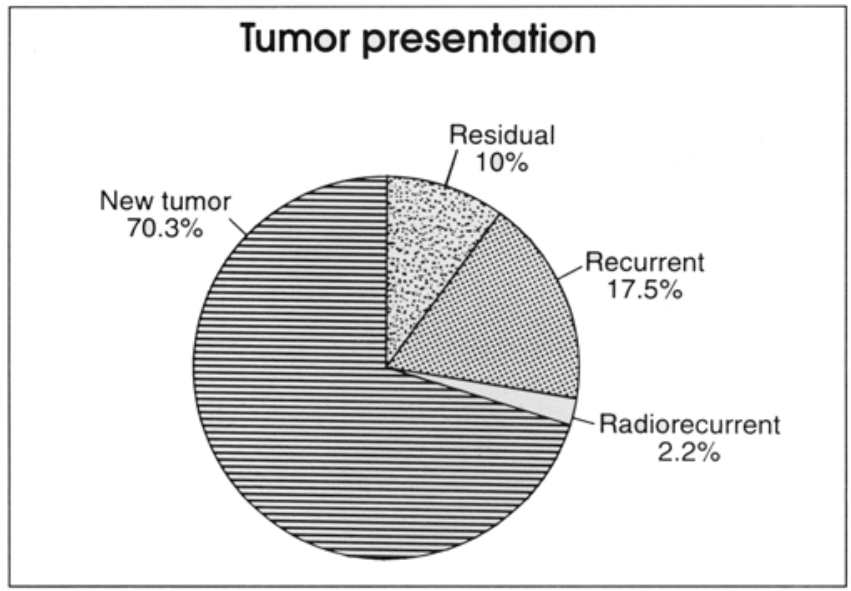

Figure 1) Tumour presentation for all patients in the series

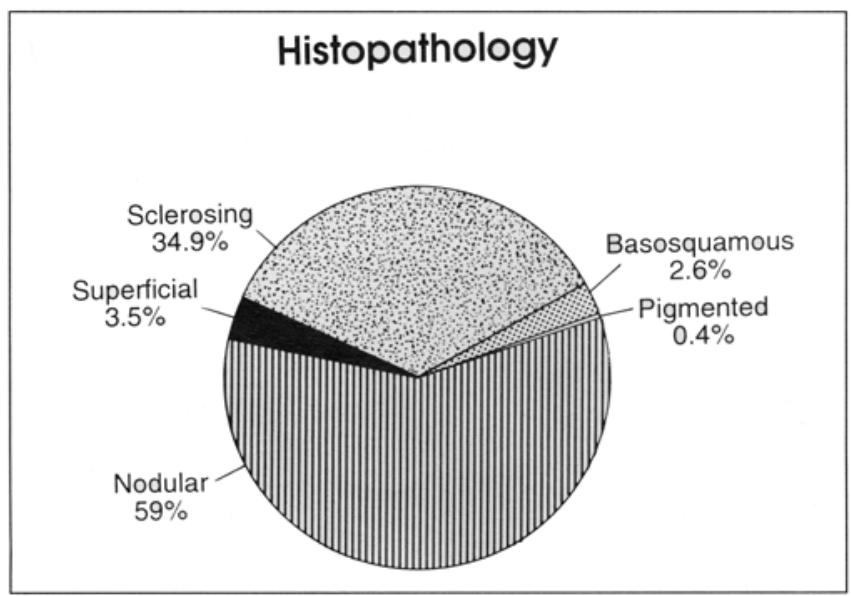

Figure 2) Histopathology for all patients in the series

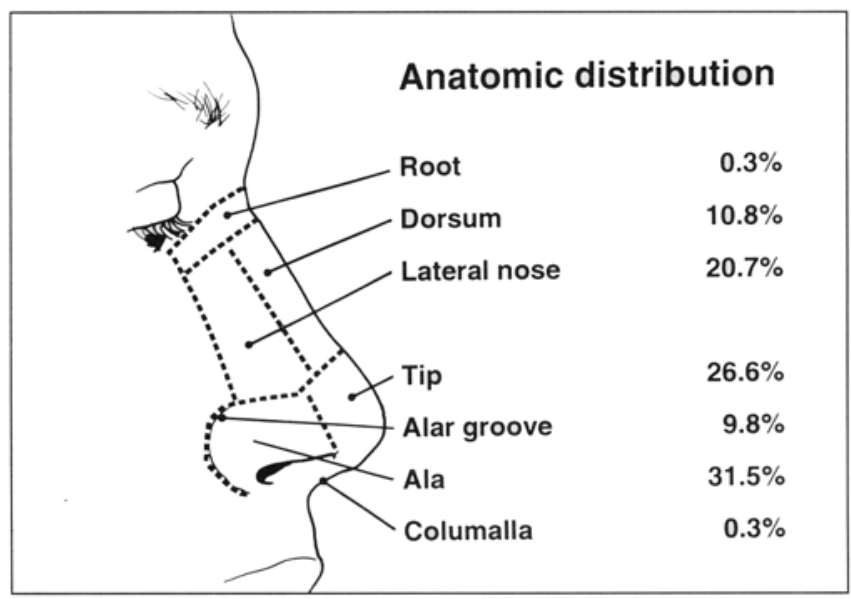

Figure 3) Distribution of all nasal basal cell carcinomas, by anatomic site 
Treatment: The standard treatment modalities included electrodessication and curettage, radiotherapy and surgical excision (Table 1). Electrodessication and curettage was employed in 26 patients. Tumours treated by this modality tended to be small (mean diameter $4.4 \mathrm{~mm}$ ) and had the shortest times to presentation. The vast majority $(92 \%)$ were new basal cell carcinomas. This modality was not used for recurrent tumours.

TABLE 1: Comparison of treatment modalities

\begin{tabular}{|c|c|c|c|c|}
\hline & Curettage & Radiotherapy & $\begin{array}{l}\text { Surgery - } \\
\text { FS }\end{array}$ & Surgery + FS \\
\hline $\begin{array}{l}\text { Number of patients } \\
(\mathrm{n}=229)\end{array}$ & 26 & 101 & 47 & 55 \\
\hline Mean age & 68.6 & 69.8 & 67 & 60.6 \\
\hline $\begin{array}{l}\text { Mean time to } \\
\text { presentation }\end{array}$ & $\begin{array}{l}7.7 \\
\text { months }\end{array}$ & 25.38 months & 17.2 months & 25.4 months \\
\hline $\begin{array}{l}\text { Mean size at } \\
\text { presentation }\end{array}$ & $4.4 \mathrm{~mm}$ & $12.1 \mathrm{~mm}$ & $7.9 \mathrm{~mm}$ & $13.1 \mathrm{~mm}$ \\
\hline \multicolumn{5}{|l|}{$\begin{array}{l}\text { Tumour presentation } \\
(\%)\end{array}$} \\
\hline New & 92.3 & 61.4 & 83 & 65.5 \\
\hline Residual & 7.7 & 10.9 & 12.8 & 7.3 \\
\hline Recurrent & 0 & 27.7 & 4.3 & $\begin{array}{l}27.3(50 \% \\
\text { radiorecurrent })\end{array}$ \\
\hline \multicolumn{5}{|l|}{ Pathology (\%) } \\
\hline Nodular & 80.8 & 62.4 & 72.3 & 30.9 \\
\hline Sclerosing & 7.7 & 31.7 & 23.4 & 63.6 \\
\hline Superficial & 11.5 & 3 & 0 & 3.6 \\
\hline Pigmented & 0 & 0 & 0 & 1.8 \\
\hline Basosquamous & 0 & 3 & 4.3 & 0 \\
\hline
\end{tabular}

Radiotherapy was used in the treatment of 101 patients. These patients had relatively long times to presentation and relatively large tumours (mean diameter 12.1 $\mathrm{mm}$ ). Although the majority were new tumours, a significant percentage of these tumours were recurrent. Just less than two-thirds of the tumours were nodular and one-third were sclerosing basal cell carcinomas.

Surgery was the modality of choice in 102 patients, 47 of which underwent tumour excision without frozen section control and 55 with frozen section control. Frozen section control was employed for large tumours (mean diameter $13.1 \mathrm{~mm}$ ), recurrent tumours (especially after irradiation 27.3\%), and those with indistinct margins; 63.6\% were sclerosing basal cell carcinomas. 
Reconstruction: One hundred and two of the 229 patients were treated surgically. The reconstructive modality depended on the size and location of the defect. In 43 patients the defects were closed primarily. These tumours were all small and their closure did not compromise cosmesis.

Local flaps were used in 54 patients of which 26 were nasolabial flaps (Figure 4). The next most common flap in this group was the glabella flap (Figure 5) followed by the dorsal nasal flap.

Skin grafts were used in seven patients. Our preferred donor site was the supraclavicular region. These tumours were too large to be easily reconstructed with local options.
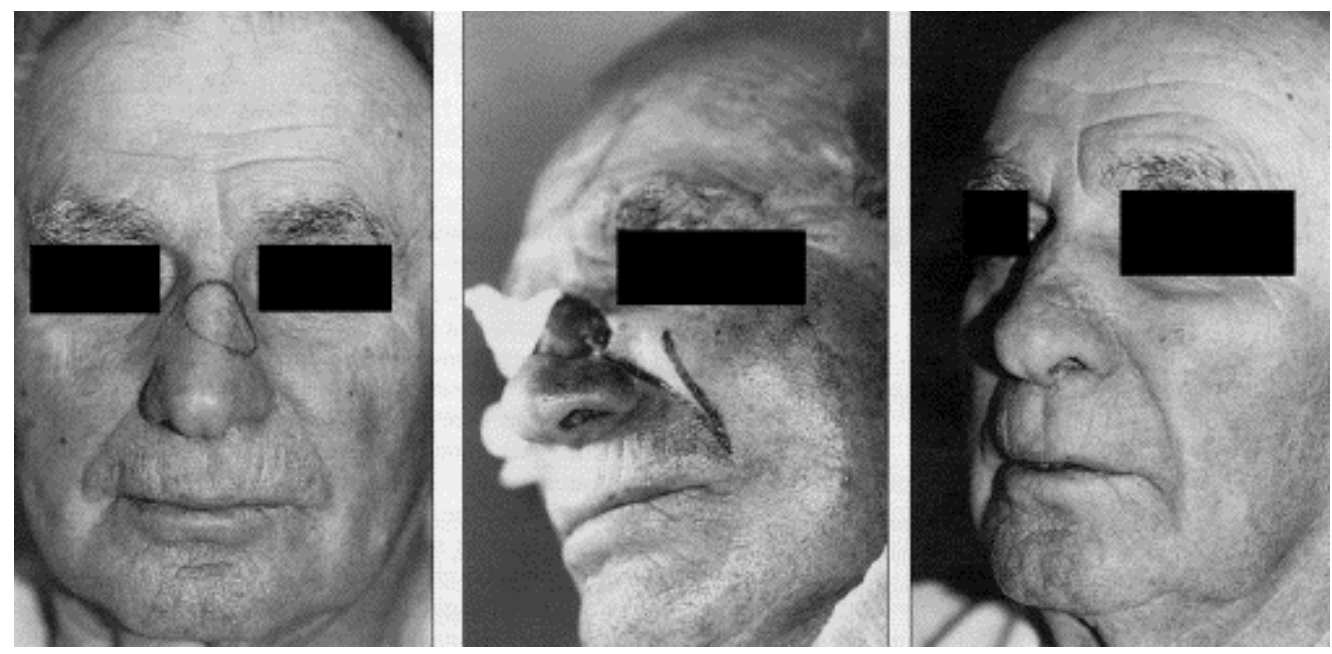

Figure 4 A 65-year-old male with a sclerosing basal cell carcinoma of the dorsum (left). This was resected with frozen section control, and a nasolabial flap was designed (middle). Final result four months later (right)
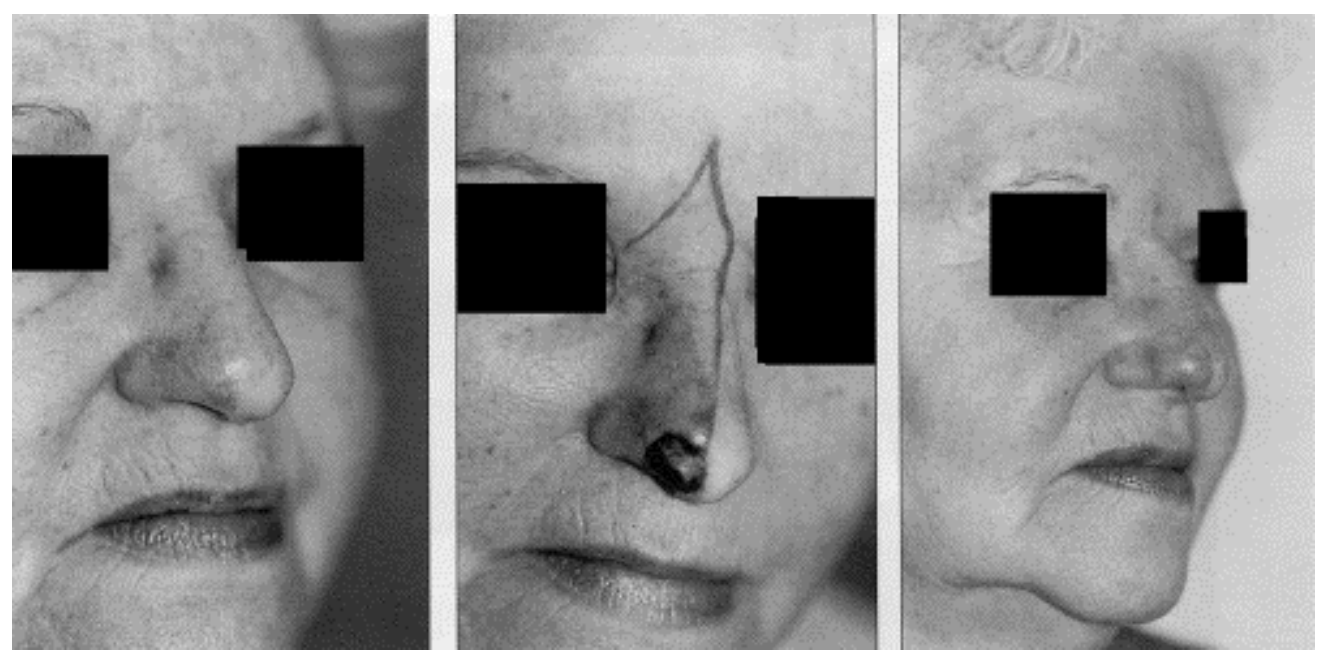

Figure 5 A 61-year-old female with a sclerosing basal cell carcinoma of the right ala and tip (left). This was excised with frozen section control and a glabellar flap was designed (middle). The patient six months later (right) 
A regional flap was used in one patient (Figure 6), with a near total nasal defect, with a very acceptable final result.

\section{DISCUSSION}

The skin of the nose is a frequent site of malignancy, most of which are basal cell carcinomas (2,4,9-11). Risk factors include sun exposure, arsenic ingestion, previous radiation and immunosuppression (12). Fortunately, the vast majority grow locally and metastasis is rare (2). However, surgical reconstruction following excision of these tumours provides aesthetic challenges.

The nose is thought of as a 'high risk location' since the recurrence rates for basal cell carcinomas are relatively high $(6,9,13)$. Potential causative factors include relationship to embryologic fusion planes (6), a tendency to spread subcutaneously but rarely to invade the perichondrium, difficulty in accurately assessing the margins (1) and inadequate margins secondary to aesthetic reconstructive concerns $(9,14)$.

The typical patient in our series is a female in her 60 s with a nodular basal cell carcinoma on the ala. This is similar to other large published series $(2,9)$. All tumours were locally invasive. There were no cases of metastases. In another large series only one basal cell carcinoma in 396 patients metastasized to the lung (2).

The ala was the most commonly involved site followed by the tip. This is similar to the observed anatomical distribution in other series $(2,5,9)$. Cancers of the root and the columella were rare. The predilection for the ala and absence of columellar involvement possibly reflects the role of sun exposure.

Patients are seen in a multidisciplinary clinic and assessed by a plastic surgeon, dermatologist and a radiation oncologist. Treatment modalities are discussed in detail with each patient and individuals are advised as to which modality is most suitable. Occasionally, however, some patients may opt for a nonsurgical modality, given their preference for a less invasive method of tumour treatment or the inconvenience of multiple visits to the clinic required for radiotherapy.

Electrodessication and curettage was reserved for small nodular and superficial tumours $(n=26)$. Electrodessication is best used for small tumours, relatively early in their natural history (13).

Radiotherapy was employed in 101 patients. The current protocol features a total dose of 3500cGy in five fractions or 4000cGy in 10 fractions. Long-term difficulties, including carcinogenesis and radiation dermatitis, argue against its use in patients under 50 years of age (15). Recurrent tumours are likely best treated by surgical excision with frozen section control (16). The indications for radiotherapy in our clinic include advanced age (more than 60 years ), relatively large tumour, nonsclerosing subtypes, contraindication to surgery for medical reasons, and cosmetic result versus surgery. Since radiotherapy requires daily visits to the treatment center, social circumstances such as distance from the center also must be considered.

Surgery was performed in 102 patients. Fort-seven patients with mostly new, nodular tumours that were of intermediate size $(7.9 \mathrm{~mm})$ were treated with surgery alone. These tumours are easily removed by direct excision without the need for frozen section control. Frozen section control of margins is reserved for sclerosing or recurrent (especially after radiation) or large basal cell carcinomas and aesthetic concerns (nasal tip 
and ala). The use of frozen section control has the distinct advantage of allowing minimal sacrifice of normal tissue and maximal cure.

There are many methods of reconstruction. A significant number of patients $(n=43)$ had the resultant defects closed primarily. Of the 54 patients that had local flaps 26 were nasolabial. The nasolabial flap is very versatile and robust and thus we use it frequently (Figure 4). The forehead flap is reserved for more extensive defects ( Figure 6 ).
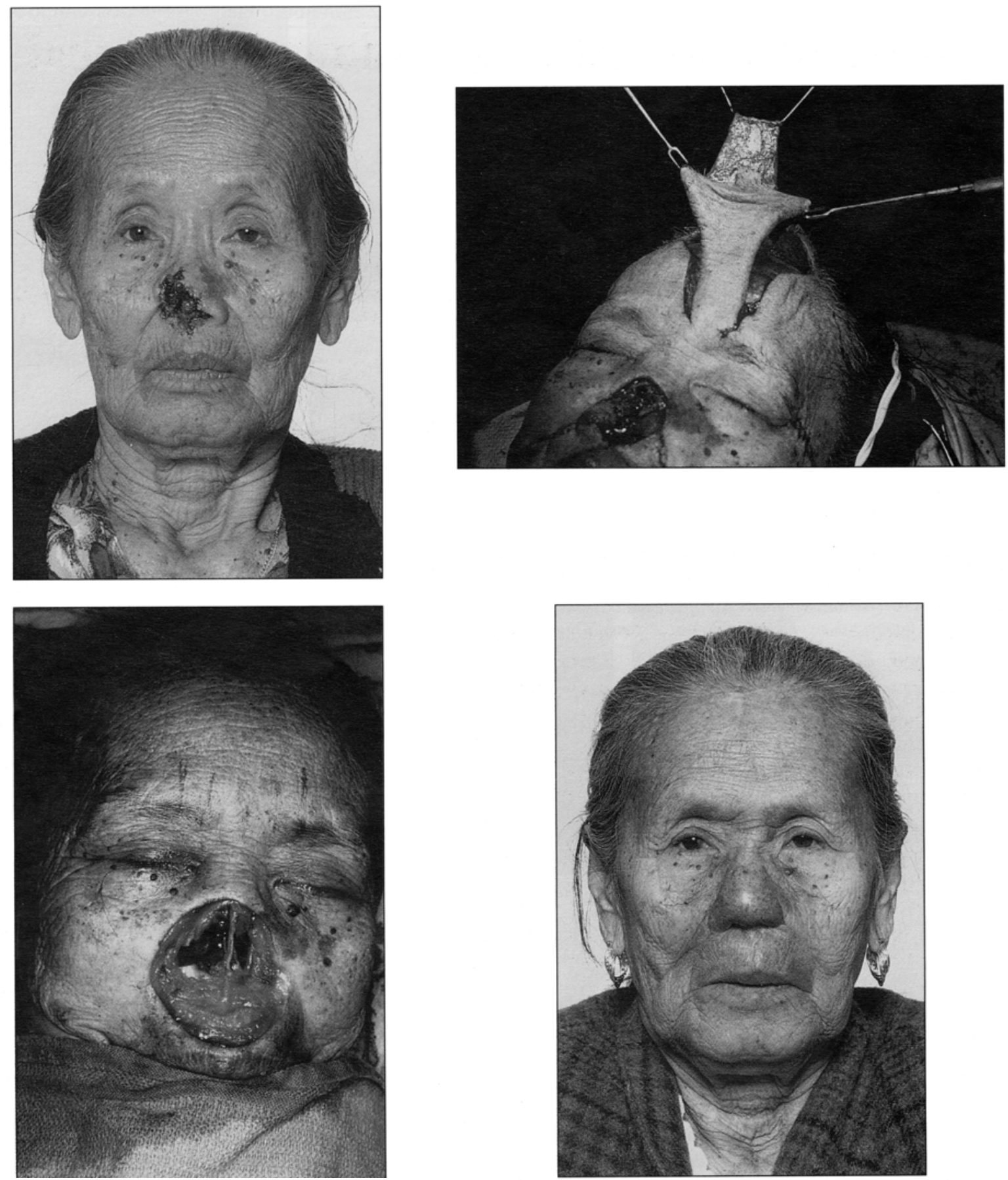
Figure 6) A 78-year-old female with a biopsy proven basal cell carcinoma (top left). This was excised with frozen section control and resulted in a near total rhinectomy (bottom left). The lining was reconstructed with nasolabial flaps, support was provided by iliac crest cantilever bone graft (dorsal and caudal strut) and septal cartilage (lateral struts). A forehead flap with a galeal extension was used for coverage (top right). Final result seven months later (bottom right)

\section{CONCLUSION}

In this retrospective study of 226 patients with basal cell carcinomas of the nose, there is a female predilection with the ala being the most common site. Treatment options include electrodessication and curettage, surgical excision or radiotherapy. Frozen section analysis of margins is invaluable in ensuring complete removal of the tumour and preservation of noninvolved skin.

\section{REFERENCES}

1. Cottel WI. Skin tumors I: Basal cell and squamous cell carcinoma. Sel Readings Plast Surg 1992; 7(6):1-34.

2. Conley J. Cancer of the skin of the nose. Ann Otol 1974;83:3-8.

3. Teichgraeber JF, Goepfert H. Rhinectomy: Timing and reconstruction. Ololaryngol Head Neck Surg 1990;102(4):362-9.

4. Petrovich ZP, Kuisk H, Langholz B, et al. Treatment results and patterns of failure in 646 patients with carcinoma of the eyelids, pinna and nose. Am J Surg 1987;154:447-50. 5. Childers BJ, Goldwyn RM, Ramos D, Chaffey JRH. Long-term results of irradiation for basal cell carcinoma of the skin of the nose. 1994;93:1169-73.

6. Shanoff LB, Spira M, Hardy SB. Basal cell carcinoma: A statistical approach to rational management. Plast Reconstr Surg 1967;39:619-24.

7. Kopf AW. Computer analysis of 3531 basal cell carcinomas of the skin. J Dermatol 1979;6; 267-81.

8. Roenigk RK. Trends in the presentation and treatment of basal cell carcinomas. J Dermatol Surg Oncol 1986;12:860-5.

9. Goepert H, Ballantyne AJ, Luna MA. Cancer of the skin of the nose. Arch Otol 1976;102:90-5.

10. Deutsch HL, Orentreich N. Treatment of small external cancers of the nose. Ann Plast Surg 1979;3:567-71.

11. Baker SR, Swanson NA. Management of nasal cutaneous malignant neoplasms. Arch Otolaryngol 1983;109:473-8.

12. Betchel MA, Callen JP, Owen LG. Etiologic agents in the development of skin cancer. Clin Plast Surg 1980;7:265-75.

13. Dubin N, Kopf AW. Multivariate risk score for recurrence of cutaneous basal cell carcinomas. Arch Derm 1983;119:373-7.

14. Taylor GA, Barisoni D. Ten years experience in the surgical treatment of basal-cell carcinoma. A study of factors associated with recurrence. Br J Plast Surg 1973;60:522-9. 15. Preston DS, Stern RS. Nonmelanoma cancers of the skin. N Engl J Med 1992;327:1649-62.

16. Menn H, Robins P, Kopf AW, Bart RS. The recurrent basal cell epithelioma. Arch Derm 1971;103:628-31. 